\title{
Food Product Design with Wijaya Kusuma Character Based on Pleasurable Design
}

\author{
Johan Paing Heru Waskitoํㅜ Endang Retno Wedowati²*, Fungki Sri Rejeki ${ }^{2}$, Emmy Wahyuningtyas ${ }^{3}$ \\ ${ }^{1}$ Department of Civil Engineering, Universitas Wijaya Kusuma Surabaya, Surabaya, Indonesia \\ ${ }^{2}$ Department of Agroindustrial Technology, Universitas Wijaya Kusuma Surabaya, Surabaya, Indonesia \\ ${ }^{3}$ Department of Informatics, Universitas Wijaya Kusuma Surabaya, Surabaya, Indonesia \\ *Corresponding author E-mail: wedowati@uwks.ac.id
}

\begin{abstract}
Manuscript received 1 Jan 2022; revised 10 Jan 2022; accepted 15 Jan 2022. Date of publication 20 Jan 2022
Abstract

Understanding and appreciation of the identity of the Universitas Wijaya Kusuma Surabaya with the motto Anggung Wimbuh Linuwih, which means always growing and developing for the better, needs to be done. The strategy that can be applied is to design a superior product that has the character of Wijaya Kusuma This food product was designed with the nuances of the character of Wijaya Kusuma. The product that reviewed in this research is chocolate product. Food product design in this study used the concept of pleasurable design, which reviews product design from the aspects of functionality, usability, and pleasure. Pleasurable design was chosen with the consideration that this product design method involves customers as product users to participate in building product designs as needed and wanted. The purpose of this study was to determine the attributes of chocolate products according to market demand, as well as to design a chocolate product design with the character of Wijaya Kusuma values. Based on the research results obtained 16 product configurations based on seven product attributes (taste, sweetness level, texture, shape, packaging method, health benefits, and appearance/profile). Attributes that have a high importance value are attributes of appearance/profile and taste. Attributes of appearance/profile can directly describe the character of Universitas Wijaya Kusuma Surabaya. while the taste attribute is one of the key attributes in food products. Product design 5 (chocolate taste, slightly sweet, texture of slightly hard, rectangle shape, folded packaging method, no preservatives, and UWKS logo profile) became the selected product with a total utility value of 10.75 .
\end{abstract}

Keywords: Product Design, Food, Chocolate, Pleasurable Design, Conjoint Analysis.

\section{Introduction}

Universitas Wijaya Kusuma Surabaya has been established by the Wijaya Kusuma Foundation on June 19, 1981. Universitas Wijaya Kusuma Surabaya as an institution for improving education, research, analysis and counseling, culture, and technology that is enshrined in the interests of developing the community, nation and state, in line with the foundation's purpose in educating life of the nation, elevating the knowledge-poor society to become a knowledge-rich society. The motto of Anggung Wimbuh Linuwih as a motto as well as philosophy and a foundation for the development of Universitas Wijaya Kusuma Surabaya. Understanding and appreciation of the identity of the Universitas Wijaya Kusuma Surabaya with the motto Anggung Wimbuh Linuwih, which means always growing and developing to improve quality, competitiveness, relevance and strengthening of governance, accountability and public image, requires a certain strategy. One strategy that can be applied is to design superior products that have the character of Wijaya Kusuma. In order to be better known to the wider community, one of the superior products that can be designed is food products. This food product is designed with the nuances of the character of Wijaya Kusuma [1].

The products reviewed in this study were chocolate products. The selection of this product is based on the fact that chocolate products have the opportunity to be used as a culinary product of the Universitas Wijaya Kusuma Surabaya. Food product design in this study used the pleasurable design concept which review product design from the aspects of functionality, usability, and pleasure [2] [3] .

Customer wants and needs are constantly changing and tend to vary. These changes in customer wants and needs tend to be increasingly diverse, both in terms of design, quality, and delivery process [4]-[6]. These increasingly diverse customer wants and needs require manufacturers to be able to produce varied products. This research is expected to produce variants of chocolate products that are in accordance with the wants and needs of customers, but still characterize the special character of Universitas Wijaya Kusuma Surabaya. Including product packaging designs which can also be used as promotional media to introduce Universitas Wijaya Kusuma Surabaya to the wider community [7] [8]. 
This research aimed to determine the attributes of chocolate products that are in accordance with the wants and needs of consumers, as well as to design a chocolate product design with the character of the value of Wijaya Kusuma in accordance with the wants and needs of consumers [9] [10].

\section{Literature Review}

\subsection{Chocolate products}

Cocoa (Theobroma cacao) is one of the mainstay commodities of plantations whose role is quite important for the national economy, especially as a provider of jobs, sources of income, and foreign exchange. Indonesia is the third largest cocoa producing country in the world after Ivory Coast and Ghana. As a cocoa-producing country, the level of chocolate consumption of Indonesian people is still very small when compared to Europeans who do not produce cocoa [11].

Chocolate is obtained by the process of mixing its constituent ingredients, size reduction, printing, and packaging. The process of size reduction aims to obtain the required level of smoothness to obtain the expected texture (mouthfeel). Some types of chocolate require a heating step before or after size reduction to facilitate the process. In addition, the heating process can be carried out to get a certain aroma and taste. The printing process is usually accompanied by a cooling process. Cooling speed can have an impact on the texture and appearance of the final product. Furthermore, chocolate is packaged in various sizes and shapes as needed [12].

\subsection{Food product design}

The concept of food product quality in general can be divided into two factors, namely intrinsic attributes and extrinsic attributes. Intrinsic attributes are attributes that measure the quality of a product based on its function and physical properties. Intrinsic attributes are specific to each product. This attribute will be lost when the product is consumed and cannot be changed without changing the nature of the product itself. Extrinsic attributes are aspects that are related to the product but are not physically part of the product itself, such as the name or image, brand, and price. These attributes are known as variables that provide product information and should be considered in the evaluation of product characteristics.

This study applied the concept of pleasurable design, where product attributes were based on aspects of functionality, usability, and pleasure [13]. By using pleasurable design, it is hoped that the attributes that have not appeared in the intrinsic and extrinsic attributes will be revealed. In addition, the application of pleasurable design involves humans, so that product design will be able to meet consumer expectations as product users [2], [3].

Based on the three aspects of pleasurable design (functionality, usability, and pleasure), the product configuration is developed by fulfilling these three aspects. It is hoped that by involving these three aspects, product design will be able to meet consumer expectations, which will increase customer satisfaction [2]. Customer satisfaction will contribute to creating consumer loyalty [14], [15]. Loyal customers will benefit the company, among which they will promote the products or services that the company produces. In addition, in designing product designs, quality aspects must also be considered.

Functionality aspect is the most basic aspect demanded by consumers, namely the ability of the product to fulfill its function. To fulfill its function, food products must have certain attributes to meet the basic wants and needs of consumers. Usability aspect is an aspect that consumers want after the functionality aspect is met. After consumers are familiar with the right functions, consumers want products that are easy to use or in the context of food products that are easy to consume. While the pleasure aspect is the aspect that consumers want after the functionality and usability aspects are met. After the product can fulfill functional benefits and is easy to use, consumers will want something more (extra). In other words, the pleasure aspect is the aspect that consumers want for the extra attributes possessed by the product, not only functional benefits but also related to the emotional aspects of consumers.

Several previous studies have conducted studies on product quality attributes in the food industry, as shown in Table 1.

Table 1. Food products attributes

\begin{tabular}{|c|c|c|c|}
\hline No. & Authors & Products & Product Attributes \\
\hline 1. & {$[16]$} & Food products & $\begin{array}{l}\text { Intrinsic: color, aroma, taste. and texture } \\
\text { Extrinsic: brand, price, and context }\end{array}$ \\
\hline 2. & [17] & Traditional food & $\begin{array}{l}\text { Intrinsic: color, taste, aroma, appearance } \\
\text { Extrinsic: brand, denomination of origin, and image }\end{array}$ \\
\hline 3. & {$[18]$} & dry-cured ham & $\begin{array}{l}\text { Intrinsic: appearance, aroma, taste, and texture } \\
\text { Extrinsic: price, nutrition value, and processing condition }\end{array}$ \\
\hline 4. & {$[19]$} & Fruit juice & $\begin{array}{l}\text { Extrinsic: brand, nutrition contents, ingredient label, shelf life, price, } \\
\text { and country of manufacture }\end{array}$ \\
\hline 5. & {$[20]$} & $\begin{array}{l}\text { milk, meat, fruits and } \\
\text { vegetables, fish }\end{array}$ & Sustainability, health, taste, and price \\
\hline 6. & {$[21]$} & Onion concentrate & Taste, aroma, and texture \\
\hline 7. & {$[2],[22]$} & Ice cream & $\begin{array}{l}\text { Functionality: taste, color, aroma, texture, and nutrition content } \\
\text { Usability: shape, size, and packaging material } \\
\text { Pleasure: brand/image, health benefits, appearance, and packaging } \\
\text { design }\end{array}$ \\
\hline
\end{tabular}

\section{Methods}

This research was designed in two stages as shown in Figure 1. The first stage is empirical research using survey methods, while the second stage is analytical research using mathematical-statistical modeling. The stages of the research can be briefly explained as follows: 1) The stage of determining product attributes, namely the stage of capturing consumer preferences related to chocolate product attributes that are used as the basis for product design, this stage used a survey method; and 2) Product design stage, to determine the 
variety of chocolate products that consumers want; at this stage used Orthogonal Design to build product configurations, and Conjoint Analysis to select product variations.

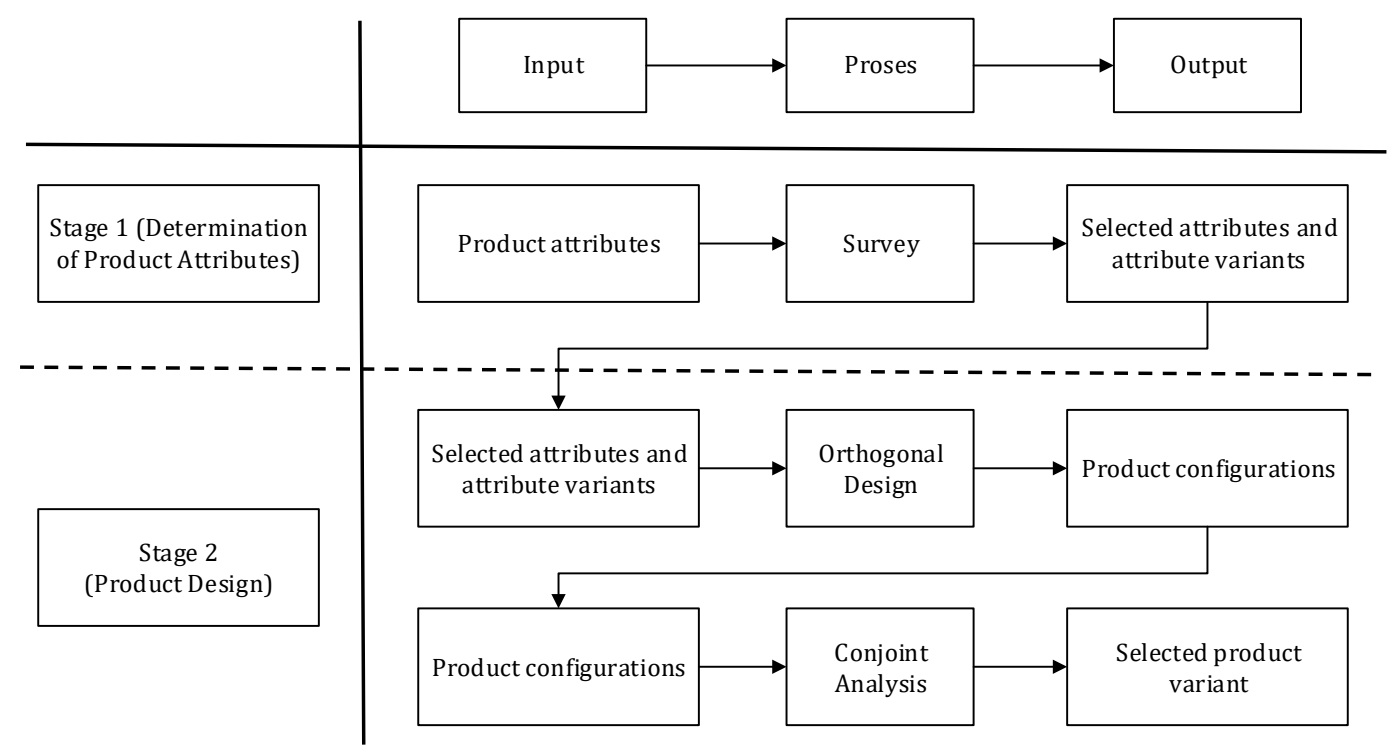

Fig 1. Stages of Research

\subsection{Product attributes determination stage}

The first stage in this research was the stage of determining product attributes. This stage was carried out to capture consumer preferences related to chocolate product attributes which are used as the basis for product design. Product attribute selection was based on the pleasurable design concept, which considers three aspects, namely functionality, usability and pleasure. This stage used the online survey method.

The questionnaire was structured in two parts, the first part is the demographic aspect of the respondents and the second part is related to the product attributes that consumers want. In the demographic aspect of respondents, the questions include age, gender, education level, occupation and income. While the product attributes reviewed in this study include aspects of functionality, usability, and pleasure aspects.

Data collection used online questionnaires distributed through social media over a predetermined period of time. Social media is used with the aim that only respondents who are interested in the product being studied will fill out the questionnaire. The target respondents are consumers of chocolate products. Data about the characteristics of respondents and their preferences were analyzed using descriptive analysis.

\subsection{Product design stage}

Alternative product configurations were developed using orthogonal design. Each aspect in pleasurable design is represented by two attributes that are most in demand by consumers, and each attribute has at least two variants that are most chosen by consumers.

Based on the alternative product configurations formed, then a ranking process is carried out to determine the ranking of the alternative product configurations. The ranking process uses the Conjoint Analysis method. Conjoint analysis is one of the most popular techniques for assessing customer preferences for product alternatives with multiple attributes [23], [24]. At this stage, the top three rankings will be selected as the selected product.

Conjoint Analysis mathematical model formulations in [24] are generally presented in Equation (1).

$U_{k}=\beta_{0}+\sum_{i=1}^{m} \sum_{j=1}^{n} u_{i j k}$

Definition:

$U_{k}=$ total utility for each alternative product configuration

$\beta_{0}=$ constant

$u_{i j k}=$ alternative utility of product configuration $k$ for attribute $i$ and level $j$

$m=$ number of attributes

$n=$ number of levels

\section{Results and Discussion}

\subsection{Data collection}

Data was collected through an online questionnaire for one month in April 2021 and distributed through social media. The targeted respondents are consumers of chocolate products. During one month of distributing the questionnaire, 216 respondents gave responses. 
The questionnaire was structured in two parts, the first part is the demographic aspect of the respondents and the second part is related to the product attributes that consumers want. In the demographic aspect of respondents, the questions include age, gender, education level, occupation and income. While the product attributes reviewed in this study include aspects of functionality, usability, and pleasure.

In this study, the attributes based on the functionality aspect that were reviewed included taste, color, aroma, texture, sweetness level, and type of chocolate. Attributes based on usability aspects that are reviewed include shape, size, packaging material, and packaging method. Meanwhile, the attributes based on the pleasure aspect that are reviewed include brand/image, health benefits, and product appearance/profile.

\subsection{Descriptive analysis}

Descriptive analysis was used to describe the characteristics of the respondents, which include age, gender, education level, occupation, and income. The results of the frequency analysis related to the characteristics of the respondents are shown in Table 2 . Descriptive analysis was also used to describe the attributes that consumers want for chocolate products. The results of the full analysis can be seen in Table 3.

Table 2. Respondents Characteristics

\begin{tabular}{|c|c|c|c|}
\hline No. & Categories & Number & Percentage (\%) \\
\hline \multirow[t]{8}{*}{ I } & Age & & \\
\hline & $<=20$ & 71 & 32.87 \\
\hline & $21-30$ & 58 & 26.85 \\
\hline & $31-40$ & 27 & 12.50 \\
\hline & $41-50$ & 20 & 9.26 \\
\hline & $51-60$ & 36 & 16.67 \\
\hline & $>=61$ & 4 & 1.85 \\
\hline & Total & 216 & 100.00 \\
\hline \multirow[t]{4}{*}{ II } & Gender & & \\
\hline & Male & 87 & 40.28 \\
\hline & Female & 129 & 59.72 \\
\hline & Total & 216 & 100.00 \\
\hline \multirow[t]{5}{*}{ III } & Education level & & \\
\hline & Middle/high school & 39 & 18.06 \\
\hline & Graduate & 103 & 47.69 \\
\hline & Post-graduate & 74 & 34.26 \\
\hline & Total & 216 & 100.00 \\
\hline \multirow[t]{7}{*}{ IV } & Occupation & & \\
\hline & Civil servants & 7 & 3.24 \\
\hline & Lecturer/teacher & 67 & 31.02 \\
\hline & Private employee & 27 & 12.50 \\
\hline & Entrepreneur & 10 & 4.63 \\
\hline & Student & 105 & 48.61 \\
\hline & Total & 216 & 100.00 \\
\hline \multirow[t]{8}{*}{$\mathrm{V}$} & Income (IDR) & & \\
\hline & $<2,000,000$ & 98 & 45.37 \\
\hline & $2,000,000-4,000,000$ & 22 & 10.19 \\
\hline & $4,000,000-6,000,000$ & 51 & 23.61 \\
\hline & $6,000,000-8,000,000$ & 17 & 7.87 \\
\hline & $8.000 .000-10.000 .000$ & 17 & 7.87 \\
\hline & $>10.000 .000$ & 11 & 5.09 \\
\hline & Total & 216 & 100.00 \\
\hline
\end{tabular}

Table 3. Consumer Preferences for Each Attribute in Each Aspect

\begin{tabular}{lclccc}
\hline \multicolumn{2}{c}{ Functionality } & \multicolumn{3}{c}{ Aspects } & \multicolumn{2}{c}{ Pleasure } \\
\hline \multicolumn{1}{c}{ Attributes } & Percentage (\%) & Attributes & Percentage (\%) & Attributes & Percentage (\%) \\
\hline \multirow{2}{*}{ Taste } & 88.1 & Shape & 71.9 & Health benefits & 70.5 \\
\hline Sweetness level & 65.1 & $\begin{array}{l}\text { Packaging } \\
\text { method }\end{array}$ & 69.4 & Brand/image & 67.5 \\
\hline Texture & 57.4 & Size & 67.7 & Appearance/profile & 56.4 \\
\hline Aroma & 56.2 & $\begin{array}{l}\text { Packaging } \\
\text { material }\end{array}$ & 55.7 & & \\
\hline Type of chocolate & 52.3 & Label & & & \\
\hline Color & 40.0 & & & & \\
\hline
\end{tabular}




\subsection{Determination of attributes}

\subsubsection{Functionality aspect}

In this study, the attributes that consumers want for chocolate products based on functionality aspects include taste, color, aroma, texture, and sweetness level. Based on these attributes, the attributes that are more chosen by consumers are then selected. The survey results show that the selected attributes are taste attributes $(88.1 \%)$, sweetness level $(65.3 \%)$, and texture $(57.4 \%)$. These three attributes from the functionality aspect will be used to build the product configuration.

Based on taste attributes, the variants offered to consumers include chocolate, strawberry, vanilla, green tea, and milk flavors. However, based on the results of the survey, the taste variants that consumers want are very diverse, apart from what has been previously mentioned, other taste variants have been revealed including: coffee, caramel, tiramisu, and others. The variants most chosen by consumers were chocolate (73.4\%), milk (44.2\%), and vanilla (39.9\%).

Based on the sweetness level attribute, there are three levels that consumers are interested in, namely slightly sweet (42.6\%), neutral $(41.7 \%)$, sweet $(41.3 \%)$. Meanwhile, for the texture attribute, there are two variants that consumers are interested in, which are a slight hard $(64.5 \%)$ and soft $(41.0 \%)$. To build the product configuration, from the functionality aspect, it is represented by three attributes, namely taste with three variants (chocolate, milk, and vanilla), sweetness level with three variants (slightly sweet, neutral, sweet), and texture with two variants (slightly hard and soft).

\subsubsection{Usability aspect}

Usability aspect is an aspect that consumers want after the functionality aspect is met [13]. After consumers are familiar with the right functions, consumers want products that are easy to use or in the context of food products that are easy to consume. Attributes that can be revealed from the usability aspect in this study include shape, size, packaging material, packaging method, number of packages and labels. Based on these attributes, the attributes that are more chosen by consumers are then selected. The survey results show that the selected attributes are shape $(71.9 \%)$ and packaging methods $(69.4 \%)$. These two attributes from the usability aspect will later be used to build product configurations.

Based on shape attributes, the variants offered to consumers include circle, square, and rectangular shape variants. However, based on the survey results, the shape variants that consumers want are very diverse, apart from what was previously mentioned, the oval and love variants were revealed. The variants most chosen by consumers are rectangular (77.3\%), circle (47.6\%), and square (35.2\%).

Based on the attributes of the packaging method, there are two variants that consumers are interested in, namely folded (69.2\%), and glued/using adhesive glue (26.9\%). To build the product configuration, from the usability aspect it is represented by two attributes, namely the shape with two variants $(3 \times 4 \mathrm{~cm}$ rectangle and $3 \mathrm{~cm}$ diameter circle) and the packaging method with two variants (folded and glued).

\subsubsection{Pleasure aspect}

The pleasure aspect is the aspect that consumers want from the extra attributes possessed by the product, not only functional benefits but also related to the emotional aspects of consumers. Although the pleasure aspect is an extra attribute of a product, along with the increase in consumer demands, the pleasure aspect can turn into a mandatory aspect of a product. The attributes studied based on the pleasure aspect in this study include brand/image attributes, health benefits, and chocolate appearance (profile). Based on the survey results, 2 attributes were selected, namely health benefits $(70.5 \%)$ and appearance/profile $(56.4 \%)$.

The variants of health benefits attributes studied include: low sugar, low fat, antioxidant content, no preservatives, no artificial sweeteners, using natural dyes, and using natural flavorings. The variants most chosen by consumers were no artificial sweetener (70.2\%), low fat (69.8\%), and low sugar (69.4\%). Meanwhile, the variants of appearance/profile attributes studied include: Logo of UWKS, Penataran Temple, and Gajah Mada. The most popular variants are the logo of UWKS (68.2\%) and Penataran Temple (63.5\%). To build a product configuration, from the pleasure aspect it is represented by two attributes, namely health benefits with three variants (no artificial sweeteners, low fat, and low sugar) and appearance/profile with two variants (Logo of UWKS and Penataran Temple).

\subsection{Product configuration}

Product attributes and variants used to develop product configurations are product attributes selected based on descriptive analysis, which is the attribute that has the most votes based on consumer opinion. Likewise for the variance of each attribute for the three aspects studied.

The product configuration was based on the selected attributes and variants. Based on the functionality aspect, three attributes were selected, namely taste, level of sweetness, and texture. There are three variants for the taste attribute, namely chocolate, milk, and vanilla; three variants for the sweetness level attribute, namely slightly sweet, neutral, and sweet; and two variants for texture attributes, namely soft and slightly hard. Based on the usability aspect, two attributes were chosen, namely the shape and the packaging method. There are two variants for the shape, namely rectangular $3 \times 4 \mathrm{~cm}$ and circle with a diameter of $3 \mathrm{~cm}$, as well as two variants for the attributes of the packaging method, namely peeled and glued. As for the pleasure aspect, two attributes were selected, namely health benefits and appearance/profile. There are three variants for health benefits, namely without artificial sweeteners, low fat and low sugar, as well as two variants for appearance/profile attributes, namely the UWKS Logo and Penataran Temple. The attributes and variants used to build the complete product configuration are shown in Table 4.

Table 4. Attributes and Variants of Product Configuration

\begin{tabular}{llllllc}
\hline & Functionality & & \multicolumn{2}{c}{ Usability } & \multicolumn{2}{c}{ Pleasure } \\
\hline Taste & Sweetness level & Texture & Shape & $\begin{array}{c}\text { Packaging meth- } \\
\text { od }\end{array}$ & $\begin{array}{c}\text { Health } \\
\text { benefits }\end{array}$ & $\begin{array}{c}\text { Appearance/ Pro- } \\
\text { file }\end{array}$ \\
\hline Chocolate & Slightly sweet & Soft & $\begin{array}{l}\text { Rectangle } \\
3 \times 4 \mathrm{~cm}\end{array}$ & Folded & $\begin{array}{l}\text { No } \\
\text { preservatives }\end{array}$ & Logo of UWKS \\
\hline Milk & Neutral & $\begin{array}{l}\text { Slightly } \\
\text { hard }\end{array}$ & Circle $3 \mathrm{~cm}$ & Glued & Low fat & $\begin{array}{l}\text { Penataran } \\
\text { Temple }\end{array}$ \\
\hline Vanilla & Sweet & & & & Low Sugar & \\
\hline
\end{tabular}


Based on the attributes and variances in each of these attributes, when using the factorial design, we get $3 \times 3 \times 2 \times 2 \times 2 \times 3 \times 2=432$ product configurations. Due to the number of combinations that are too many and it is not possible to get respondents' ratings to compare 432 configurations, in this study to build alternative product configurations not using factorial design but using Orthogonal Design. Based on the results of the orthogonal design output, 16 product configurations were obtained, as shown in Table 5.

Table 5. List of Product Configurations

\begin{tabular}{|c|c|c|c|c|c|c|c|}
\hline \multirow[b]{2}{*}{ Design } & \multicolumn{3}{|c|}{ Functionality } & \multicolumn{2}{|c|}{ Usability } & \multicolumn{2}{|c|}{ Pleasure } \\
\hline & Taste & $\begin{array}{c}\text { Sweetness } \\
\text { Level }\end{array}$ & Texture & Shape & $\begin{array}{l}\text { Packaging } \\
\text { Method }\end{array}$ & $\begin{array}{c}\text { Health } \\
\text { Benefits }\end{array}$ & $\begin{array}{c}\text { Appearance/ } \\
\text { Profile }\end{array}$ \\
\hline 1 & Milk & Slightly sweet & Soft & Circle & Folded & Low fat & Logo of UWKS \\
\hline 2 & Chocolate & Sweet & Soft & Circle & Glued & $\begin{array}{l}\text { No } \\
\text { preservatives }\end{array}$ & Logo of UWKS \\
\hline 3 & Chocolate & Neutral & Slightly hard & Circle & Glued & Low fat & Logo of UWKS \\
\hline 4 & Vanilla & Slightly sweet & Soft & Circle & Glued & Low sugar & Penataran Temple \\
\hline 5 & Chocolate & Slightly sweet & Slightly hard & Rectangle & Folded & $\begin{array}{l}\text { No } \\
\text { preservatives }\end{array}$ & Logo of UWKS \\
\hline 6 & Vanilla & Slightly sweet & Slightly hard & Circle & Folded & $\begin{array}{l}\text { No } \\
\text { preservatives }\end{array}$ & Logo of UWKS \\
\hline 7 & Chocolate & Sweet & Soft & Circle & Folded & $\begin{array}{l}\text { No } \\
\text { preservatives }\end{array}$ & Penataran Temple \\
\hline 8 & Milk & Sweet & Slightly hard & Rectangle & Glued & Low sugar & Logo of UWKS \\
\hline 9 & Chocolate & Neutral & Slightly hard & Circle & Folded & Low sugar & Penataran Temple \\
\hline 10 & Chocolate & Slightly sweet & Soft & Rectangle & Folded & Low sugar & Logo of UWKS \\
\hline 11 & Milk & neutral & Soft & Rectangle & Folded & $\begin{array}{l}\text { No } \\
\text { preservatives }\end{array}$ & Penataran Temple \\
\hline 12 & Vanilla & neutral & Soft & Rectangle & Glued & $\begin{array}{l}\text { No } \\
\text { preservatives }\end{array}$ & Logo of UWKS \\
\hline 13 & Milk & Slightly sweet & Slightly hard & Circle & Glued & $\begin{array}{l}\text { No } \\
\text { preservatives }\end{array}$ & Penataran Temple \\
\hline 14 & Chocolate & Slightly sweet & Soft & Rectangle & Glued & $\begin{array}{l}\text { No } \\
\text { preservatives }\end{array}$ & Penataran Temple \\
\hline 15 & Chocolate & Slightly sweet & Slightly hard & Rectangle & Glued & $\begin{array}{l}\text { No } \\
\text { preservatives }\end{array}$ & Penataran Temple \\
\hline 16 & Vanilla & Sweet & Slightly hard & Rectangle & Folded & $\begin{array}{l}\text { No } \\
\text { preservatives }\end{array}$ & Penataran Temple \\
\hline
\end{tabular}

\subsection{Determination of selected product variants}

Conjoint Analysis was used to determine the ranking of the product configurations formed. Based on the product configuration formed from the orthogonal design results, a second stage survey was then carried out. The second phase of the survey was conducted to capture consumer preferences for alternative configurations of chocolate products, ranging from the most preferred to the least preferred.

Based on the results of the second phase of the survey, a conjoint analysis process was carried out. Conjoint Analysis is used to determine the estimated utility value of each attribute and its variance. Besides the total utility value, the importance values of each attribute are also obtained. The total utility value for each product configuration is used as the basis for the ranking process.

Conjoint Analysis was used to determine the ranking of product configurations. The results of the Conjoint Analysis get an estimate of the utility value of each attribute and its variance as shown in Table 6. Besides the total utility value, the importance values of each attribute are also obtained. The total utility value for each product configuration is used as the basis for the ranking process. 
Table 6. Estimated Utility for Each Attribute

\begin{tabular}{|c|c|c|}
\hline Attributes & Variants & Utility Estimate \\
\hline \multirow{3}{*}{$\begin{array}{l}\text { Taste } \\
(27.581)\end{array}$} & Chocolate & 1.677 \\
\hline & Milk & -0.729 \\
\hline & Vanilla & -0.948 \\
\hline \multirow{2}{*}{$\begin{array}{l}\text { Shape } \\
(6.490)\end{array}$} & Rectangle $3 \times 4 \mathrm{~cm}$ & 0.121 \\
\hline & Circle $3 \mathrm{~cm}$ & -0.121 \\
\hline \multirow{2}{*}{$\begin{array}{l}\text { Packaging method } \\
(9.375)\end{array}$} & Folded & 0.211 \\
\hline & Glued & -0.211 \\
\hline \multirow{3}{*}{$\begin{array}{l}\text { Health benefits } \\
(4.867)\end{array}$} & No preservatives & 0.052 \\
\hline & Low fat & -0.018 \\
\hline & Low sugar & -0.034 \\
\hline \multirow{2}{*}{$\begin{array}{l}\text { Appearance/profile } \\
(37.316)\end{array}$} & Logo of UWKS & 0.215 \\
\hline & Penataran Temple & -0.215 \\
\hline \multirow{3}{*}{$\begin{array}{l}\text { Sweetness level } \\
(5.900)\end{array}$} & Slightly sweet & -0.591 \\
\hline & Neutral & -0.182 \\
\hline & Sweet & -1.773 \\
\hline \multirow{2}{*}{$\begin{array}{l}\text { Texture } \\
(8.112)\end{array}$} & Slightly hard & 0.070 \\
\hline & Soft & 0.141 \\
\hline (Constant) & & 8.996 \\
\hline
\end{tabular}

Based on the importance values of each attribute, the appearance attribute has the highest importance value, which is 37.316 followed by the attributes of taste, packaging method, texture, shape, level of sweetness, and health benefits, and packaging materials. The taste attribute is the second most important rank attribute for ice cream products, this is in line with the opinion of [25] which states that rasa is a key driver for customer preferences.

Furthermore, based on the utility value of each variant on certain attributes, the total utility value for each product configuration can be calculated. The higher the total utility value, the more attractive the product configuration is for consumers, for example for product 1 configuration which consists of a combination of milk taste, slightly sweet, soft texture, circular shape, folded packaging method, low fat, and UWKS logo profile, based on equation (1), then the total utility value is:

$U_{1}=8,996+(-0,729)+(-0,591)+0,141+(-0,121)+0.211+(-0.018)+0,215$

$=8,10$

The above calculation process is repeated to determine the total utility value for each product configuration. Next, a ranking is determined for each product configuration based on the total utility value. The results of the total utility calculation and ranking were shown in Table 7.

Table 7. Total Utility and Ranking of Each Product Configuration

\begin{tabular}{cccccc}
\hline Design & Total Utility & Ranking & Design & Total Utility & Ranking \\
\hline 1 & 8.10 & 11 & 9 & 10.40 & 4 \\
\hline 2 & 8.98 & 7 & 10 & 10.74 & 2 \\
\hline 3 & 10.43 & 3 & 11 & 8.40 & 9 \\
\hline 4 & 7.02 & 14 & 12 & 8.18 & 10 \\
\hline 5 & 10.75 & 1 & 13 & 7.25 & 13 \\
\hline 6 & 7.88 & 12 & 14 & 9.97 & 5 \\
\hline 7 & 8.97 & 8 & 15 & 9.90 & 6 \\
\hline 8 & 6.66 & 15 & 16 & 6.51 & 16 \\
\hline
\end{tabular}

Table 7 showed that product configuration 5 was the product configuration that most consumers are interested in (rank 1) with a total utility value of 10.75 . Followed by product configuration 10 , and product configuration 3 . Based on the three product configurations, the chocolate flavor variant is the most sought after by consumers compared to other flavor variants, this can also be seen from the estimate utility value of 1,677 which is the largest estimate utility value for flavor variants.

\section{Conclusion}

Based on the results of descriptive analysis, product configuration was based on 7 attributes, namely: taste (chocolate, milk, and vanilla), sweetness level (slightly sweet, neutral, and sweet), texture (soft and slightly hard), shape (rectangular $3 \times 4 \mathrm{~cm}$ and $3 \mathrm{~cm}$ diameter circle), 
packaging method (folded and glued), health benefits (no artificial sweeteners and low fat), and appearance/profile (UWKS logo and upgrading temple). Configure the product using orthogonal design and get 16 configurations of chocolate product design.

Product configuration 5 is the product configuration that most consumers are interested in (rank 1 with a total utility value of 10.75). Followed by product configuration 10, and product configuration 3. Based on the three product configurations, the chocolate flavor variant is the most sought after by consumers compared to other flavor variants, this can also be seen from the estimate utility value of 1,677 which is the largest estimate utility value for flavor variants.

\section{Acknowledgement}

Acknowledgements to the Research and Community Service Institutions of Universitas Wijaya Kusuma Surabaya which has funded this research through Internal Research Grant with contract number 03/LPPM/UWKS/III/2021.

\section{References}

[1] M. F. Firmansyah and H. Z. Maulana, "Empirical Study of E-Learning on Financial Literacy and Lifestyle : A Millenial Urban Generations Cased Study," Int. J. Eng. Sci. Inf. Technol., vol. 1, no. 3, pp. 75-81, 2021.

[2] E. R. Wedowati, M. L. Singgih, and I. K. Gunarta, "Determination of modules in pleasurable design to fulfil customer requirements and provide a customized product in the food industry," Designs, vol. 4, no. 7, pp. 1-21, 2020, doi: 10.3390/designs 4010007 .

[3] E. R. Wedowati, M. Laksono Singgih, and I. K. Gunarta, "Product value analysis on customized product based on pleasurable design and time-driven activity-based costing in food industry," Cogent Bus. Manag., vol. 7, no. 1, 2020, doi: 10.1080/23311975.2020.1823581.

[4] R. Akkerman and D. P. Van Donk, "Product mix variability with correlated demand in two-stage food manufacturing with intermediate storage," Int. J. Prod. Econ., vol. 121, no. 2, pp. 313-322, 2009.

[5] J. D. Frutos and D. Borenstein, "A framework to support customer-company interaction in mass customization environments," Comput. Ind., vol. 54, pp. 115-135, 2004.

[6] R. I. McIntosh, J. Matthews, G. Mullineux, and a. J. Medland, "Late customisation: issues of mass customisation in the food industry," Int. J. Prod. Res., vol. 48, no. 6, pp. 1557-1574, Mar. 2010, doi: http://dx.doi.org/10.1080/00207543.2012.693963.

[7] M. Zarebnia and R. Parvaz, "A new approach for solution of telegraph equation," Int. J. Nonlinear Anal. Appl., vol. 12, no. 1, 2021, doi: 10.22075/ijnaa.2021.4811.

[8] Z. Dahmani and S. Belarbi, "New results for fractional evolution equations using Banach fixed point theorem," Int. J. Nonlinear Anal. Appl., vol. 5, no. 2, 2014, doi: 10.22075/ijnaa.2014.123.

[9] R. Dewi, N. Sylvia, and M. Riza, "The Effect of Rice Husk and Saw Dusk Filler on Mechanical Property of Bio Composite from Sago Starch,” Int. J. Eng. Sci. Inf. Technol., vol. 1, no. 3, 2021, doi: 10.52088/ijesty.v1i3.113.

[10] N. Sylvia, Y. Yunardi, H. Husni, and A. Muslim, "Simulation of CO2 Gas Adsorption Process Flow at Cyclone Gas Outlet in Palm Oil Mills Using Computation Fluid Dynamic Simulation,” Int. J. Eng. Sci. Inf. Technol., vol. 1, no. 3, 2021, doi: 10.52088/ijesty.v1i3.112.

[11] M. Suprayatmi, Mardiah, and E. R. Zein, "Pemberdayaan kelompok wanita dalam produksi olhan cokelat. Women's Empowerment in Chocolate Productions 1M," Media Pngabdian Kpd. Masy. Qardhul Hasan, vol. 1, no. 1, pp. 33-41, 2015.

[12] Anonim, Pedoman Cokelat. Jakarta: Direktorat Standarisasi Produk Pangan, Deputu Bidang Pengawasan Keamanan Pangan dan Bahan Berbahaya, Badan pengawas Obat dan Makanan., 2017.

[13] P. W. Jordan, Designing Pleasurable Products, E-Library. London: Taylor \& Francis, 2000.

[14] C. Fandos and C. Flavián, "Intrinsic and extrinsic quality attributes, loyalty and buying intention: an analysis for a PDO product," Br. Food J., vol. 108, pp. 646-662, 2006, doi: 10.1108/00070700610682337.

[15] V. Stan, B. Caemmerer, and R. Cattan-jallet, "Customer loyalty development: The role of switching costs," J. Appl. Bus. Res., vol. 29, no. 5, pp. 1541-1554, 2013.

[16] R. Iop, S.C.F.; Teixeira, E.; Deliza, “Consumer research : extrinsic variables in food studies,” Br. Food J., vol. 108, no. 11, pp. 894-903, 2006.

[17] J. Espejel, C. Fandos, and C. Flavián, "The role of intrinsic and extrinsic quality attributes on consumer behaviour for traditional food products,” Manag. Serv. Qual., vol. 17, no. 6, pp. 681-701, 2007.

[18] M. Hersleth, E. Monteleone, A. Segtnan, and T. Næs, "Effects of evoked meal contexts on consumers ' responses to intrinsic and extrinsic product attributes in dry-cured ham," Food Qual. Prefer., vol. 40, pp. 191-198, 2015.

[19] P. Y. Lee, K. Lusk, M. Mirosa, and I. Oey, "An attribute prioritization-based segmentation of the Chinese consumer market for fruit juice," Food Qual. Prefer., vol. 46, pp. 1-8, 2015, doi: http://dx.doi.org/10.1016/j.foodqual.2015.06.016.

[20] M. C. D. Verain, S. J. Sijtsema, and G. Antonides, "Consumer segmentation based on food-category attribute importance : The relation with healthiness and sustainability perceptions," Food Qual. Prefer., vol. 48, pp. 99-106, 2016, doi: http://dx.doi.org/10.1016/j.foodqual.2015.08.012.

[21] T. Nishimura et al., "Phytosterols in onion contribute to a sensation of lingering of aroma, a koku attribute," Food Chem., vol. 192 , pp. 724-728, 2016, doi: http://dx.doi.org/10.1016/j.foodchem.2015.06.075.

[22] E. R. Wedowati, M. L. Singgih, and I. K. Gunarta, "A study of consumer preferences for customized product design," in MATEC Web of Conferences, 2018, vol. 204, doi: 10.1051/matecconf/201820401002.

[23] F. S. Fogliatto and G. J. C. da Silveira, "Mass customization : A method for market segmentation and choice menu design," Int. J. Prod. Econ., vol. 111, pp. 606-622, 2008.

[24] C. H. Wang, "Integrating Kansei engineering with conjoint analysis to fulfil market segmentation and product customisation for digital cameras," Int. J. Prod. Res., vol. 53, no. 8, pp. 2427-2438, 2015, doi: 10.1080/00207543.2014.974840.

[25] S. De Pelsmaeker, J. J. Schouteten, S. Lagast, K. Dewettinck, and X. Gellynck, "Is taste the key driver for consumer preference? A conjoint analysis study," Food Qual. Prefer., vol. 62, pp. 323-331, 2017, doi: 10.1016/j.foodqual.2017.02.018. 